\title{
Meningkatkan Motorik Halus melalui Kegiatan Menggambar dengan Model Atik di TK Pertiwi VI
}

\author{
Dewi Mahmudah', Sri Watini² \\ 1,2Universitas Panca Sakti, Bekasi, Indonesia \\ E-mail: dewi.mahmudah.alwi@gmail.com, srie.watini@gmail.com
}

\begin{tabular}{|c|c|}
\hline Article Info & Abstract \\
\hline $\begin{array}{l}\text { Article History } \\
\text { Received: } 2022-02-02 \\
\text { Revised: } 2022-02-15 \\
\text { Published: 2022-02-22 }\end{array}$ & $\begin{array}{l}\text { Drawing activities are activities that are often carried out by early childhood where } \\
\text { these activities enable fine motor skills in every movement of their fingers, drawing } \\
\text { rarely has a meaningful meaning for children because they draw by crossing out an } \\
\text { article on paper. So here we need to train children's fine motor skills to get used to } \\
\text { drawing which has meaning for the reader. So if we expect early childhood to be able to } \\
\text { draw with high meaning, creativity is needed for a teacher, including the ATIK model } \\
\text { which is very effective in improving fine motor activities in drawing activities based on } \\
\text { research conducted at TK Pertiwi VI, where the This study uses a classroom action } \\
\text { research model with the results obtained are very satisfying. }\end{array}$ \\
\hline
\end{tabular}

\section{Artikel Info}

Sejarah Artikel

Diterima: 2022-02-02

Direvisi: 2022-02-15

Dipublikasi: 2022-02-2

\section{Kata kunci:}

Model ATIK;

Motorik Halus;

TK.

\begin{abstract}
Abstrak
Kegiatan menggambar merupakan kegiatan yang sering dilakukan oleh anak usia dini dimana kegiatan tersebut memfungsikan motorik halus dalam setiap gerakan jemarinya, menggambar jarang sekali mempunyai makna yang berarti bagi anak karena mereka menggambar dengan asal mencoret sebuah tulisan pada kertas. Maka disini perlu kita latih motorik halus anak agar terbiasa dalam menggambar yang mempunyai arti bagi pembacanya. Sehingga apabila kita mengharapakan anak usia dini agar dapat menggmbar dengan mempunyai makna yang tinggi maka kreatiftitas sangat dibutuhkan bagi seorang guru diantaranya dengan model ATIK yang ternyata sangat efektif dalam meningkatkan kegiatan motorik halus pada kegiatan menggambar berdasarkan penelitian yang dilakukan pada TK Pertiwi VI, dimana kegiatan kali ini menggunakan model penelitian tindakan kelas dengan hasil yang didapatkan sangat memuaskan.
\end{abstract}

\section{PENDAHULUAN}

Setiap anak diharapkan memperoleh pendidikan yang baik dalam lingkungannya, baik lingkungan keluarga maupun sekolah, karena pendidikan bagi anak usia dini sangat fundamental, sehingga setiap rangsangan yang diterima akan sangat berpengaruh pada anak tersebut. Stimulus yang diberikan kepada anak akan menjadi motivasi tersendiri bagi anak. Kemampuan anak dalam menggunakan jari jemari juga sangat berpengaruh dalam kegiatan anak. Mereka belum bisa memegang pensil maka kita harus sabar dan telaten membimbingnya sehingga mereka harus mampu memegang pensil dengan benar, adapun pengembangan kegiatan pada anak usia dini meliputi agama dan moral, social emosional, kognitif, seni, bahasa dan fisik motorik, dalam kegiatan motorik pada anak usia dini meliputi motorik halus dan motorik kasar. Mereka tidak langsung bisa menggunakan anggota tubuhnya untuk kegiatan motorik halus akan tetapi perlu waktu dan bimbingan yang terus menerus dalam menggunakan anggota tubuhnya, diantaranya yaitu kesiapan anak dalam menggambar.
Pembiasaan tentang penggunaan motoric halus yang secara terus menerusa akan sangat mempengaruhi anak tersebut, mereka akan menjadi terbiasa kalau semua anggota keluarga dan orang tua berperan dalam menggunakan jemari nya, misalnya anak akan dapat menulis, meremas kertas, memotong benda dengan menggunakan gunting atau kegiatan yang lainnya, di kelas masih sering kita jumpai anak yang menggambar belum terarah mereka menggambar asal corat coret pada suatu kertas, tanpa ada makna yang dapat dibaca oleh orang yang melihat. Menggambar merupakan kegiatan yang memerlukan gerakan tangan dalam membentuk suatu obyek. Kreativitas yang tinggi dan imajinasi sangat diperlukan dalam menggambar, karena seni merupakan ungkapan hati seseorang yang dituangkan dalam bentuk coretan, oleh karena itu peneliti ingin mengadakan penelitian tentang meningkatkan motorik halus melalui kegiatan menggambar dengan model atik di TK Pertiwi VI.

1. Motorik Halus

Dalam melakukan kegiatan, anak sering menggunakan otot otot halus dan otot kasar . 
kesemuanya berimbang sesuai aktifitas yang dijalani. Menurut artikel yang ditulis (Indraswari, 2012: 2) banyak kegiatan yang dilakukan anak menggunakan otot kasar sehingga anak dapat bermain sepak bola, berjongkok melompat, serta menendang bola. Sedangkan menurut artikel yang ditulis oleh (Marliza, 2012: 1) perkembangan gerakan motorik halus anak taman kanak-kanak ditekankan pada koordinasi gerakan motorik halus dalam hal ini berkaitan dengan kegiatan meletakkan atau memegang suatu objek dengan menggunakan jari tangan. Perkembangan otot kasar biasanya lebih dulu terjadi daripada otot halus, anak bisa merangkak, berjalan, atau membawa sesuatu, barulah perkembangan otot halus mulai berkembang, diantaranya anak dapat memegang, meremas ataupun kegiatan yang lainnya, seiring dengan hal tersebut kita berusaha untuk mengoptimalkan semua otot pada anak berjalan dengan baik, sehingga tidak akan ada keterlambatan pada anak dalam melakukan gerakan yang menggunakan fungsi otot, sehingga apabila semua fungsi seimbang maka tidak akan terjadi sesuatu yang tidak diharapkan pada anak. Adanya kemampuan motorik halus dan kasar yang kurang dilatih maka akan ada sesuatu yang kurang sehingga membuat anak-anak akan merasa minder dengan ketidak mampuannya.(Oktaviani, 2018). Keterlambatan anak dalam menggunakan fungsi otot halus maka akan mengakibatkan anak juga akan kesulitan dalam melakukan kegiatan yang lain sehingga terkadang anak akan malu kepada teman sebayanya ketika disekolah misalnya ketika anak tidak dapat menggunakan tali sepatu yang dipakainya.

\section{Menggambar}

Sebagai seorang guru, kita harus mengetahui bakat dan kemampuan yang dimiliki oleh anak. Terkadang mereka ada yang menonjol di akademik tapi tak sedikit pun ada yang menonjol di seni, Dan yang sering terjadi yang dilakukan oleh orang tua, mereka juga kurang mengetahui dengan seksama tentang bakat atau kemampuan yang dimiliki oleh anak. Padahal aktivitas yang disukai anak usia dini di sekolah yaitu menggambar, karena dengan menggambar mereka dapat mengekspresikan apa yang ia rasa dan yang ia lihat. Menggambar adalah berfikir sesuai ide, khayalan dalam bentuk suatu gagasan ataupun coretan. Bahkan banyak coretan yang dilakukan oleh anak terkadang ada perbedaan makna dari orang tua/ guru yang berbeda makna, Berdasarkan pemahaman Pamadhi, (2008: 2.19) manfaat menggambar bagi anak adalah sebagai alat bercerita, media mencurahkan perasaan, alat main, melatih ingatan, melatih berpikir komprehensif (menyeluruh), melatih keseimbangan, mengembangkan kecakapan emosional, melatih kreativitas, melatih melalui pengamatan langsung, disini peran guru sangat diperlukan dalam menggembangkan gagasan atau ide yang dibuat oleh anak. Mereka bebas untuk berekspresi, bebas menggambar apa saja yang dia inginkan dengan obyek yang dilihat langsung oleh anak, misalnya ketika menggambar buah jeruk, ada yang bentuknya agak lonjong, bulat, kecil maupun besar, kita tidak boleh menyalahkan hasil karya mereka karena itulah imajinasi yang dimiliki anak.

\section{Model Atik}

Model ATIK merupakan model pembelajaran menggambar yang dikembangkan dari Model Experiental Learning Theory (ELT) dan Model Pembelajaran tidak langsung. Model ELT dikembangkan oleh David Kolb. Experiental Learning Theory adalah suatu model proses belajar mengajar yang mengaktifkan pembelajar untuk membangun pengetahuan dan keterampilan melalui pengalaman secara langsung (Abdul Majid, 2013), dalam belajar secara langsung, anak melihat benda yang akan digambar ada dihadapan mereka sehingga anak mengetahui wujud benda secara nyata. Model pembe-lajaran tidak langsung sering disebut model pembelajaran inkuiri, pemecahan masalah, pengambilan keputusan dan penemuan (Abdul Majid, 2013). Model ini anak bisa melihat benda lewat suatu gambar atau suatu tayangan yang berada di-hadapannya. Robetson dan Lang dalam Suryadi (2005:14) mengemukakan, "Pembe-lajaran tidak langsung memiliki karakteristik salah satunya adalah Menuntut keterlibatan anak secara aktif dalam melakukan observasi, investigasi, pengambilan kesimpulan dan pencarian alternative solusi dan (Abdul Majid, 2013), dengan mengkolaborasikan model ELT dengan Model pembelajaran tidak langsung yang lebih dikenal dengan model Inkuri ini maka diperoleh model baru dengan nama model ATIK. Amati merupakan suatu proses kegiatan untuk melihat atau memperhatikan suatu obyek, 
kejadian atau peristiwa yang ada di sekitarnya.

Amati merupakan kata dasar dari mengamati ataupun pengamatan. Seluruh penglihatan akan terfokus melihat bagian benda dengan jelas dan detail setiap ruang benda . Bredekamp \& Copple (1997) menyatakan, " semua belajar bagi anak dimulai dari persepsi: melihat, mendengar, menyentuh, merasa dan mencium (Masitoh, 2005). Mereka akan mempunyai tanggapan suatu benda setelah mereka melihat dengan jelas tentang suatu benda dihadapannya. Perkembangan imitation menurut Peaget, adalah suatu kemampuan melakukan kembali perilaku yang dicontohkan (Dkk, 2011). Anak akan melakukan peniruan atau imitasi pada apa yang dilihat, didengar dan dirasakan. Peniruan dalam tahapan konseptual dapat membentuk pengertian, karena dengan perilaku imitasi di mana anak sebelumnya tidak mengerti dan setelah anak melakukan perila$\mathrm{ku}$ imitasi anak mulai mengerti apa yang dilakukannya menyenangkan atau tidak menyenangkan yaitu mendapatkan respon. positif atau negatif (Abubakar Baraja, 2008). Bandura dan Walters (1963) dalam teori belajar social menjelaskan bahwa tingkah laku dapat ditiru atau dipelajari melalui "melihat" (Abubakar Baraja, 2008). Doing dalam active experimentation menurut Kolb (Abdul Majid, 2013), anak ditempatkan pada situasi-situasi nyata dalam proses pembelajaran, Dalam konsep Model ELT (Experimental Learning Theory) ada 4 tahap dalam proses pembelajaran yaitu Concrete Experience (CE), Reflection Observation (RO),

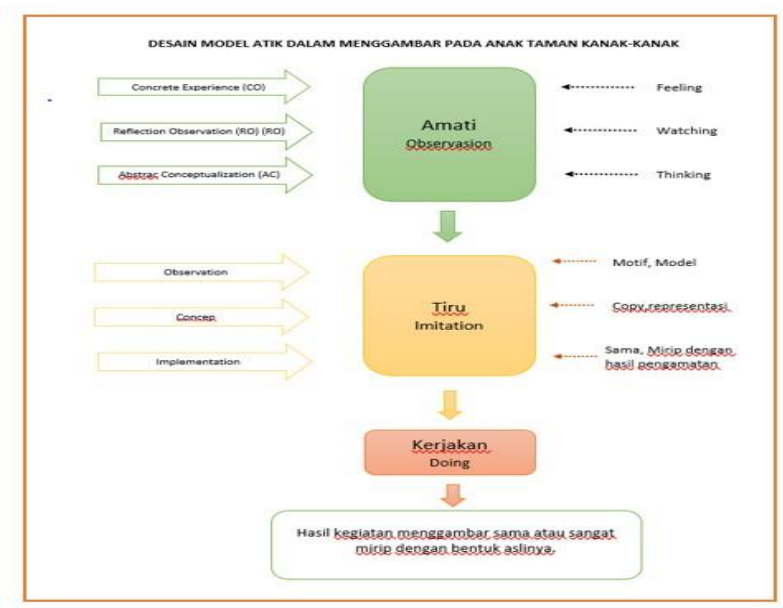

Gambar 1. Desain "Model ATIK" (Sri watini 2020)

\section{METODE PENELITIAN}

Penelitian akan dilaksanakan di TK Pertiwi VI yang beralamat di A Yani 253 Karangketug Pasuruan selama 2 minggu yaitu pada minggu ke 13 dan 14 semester I tahun pelajaran 2021-2022. Sedangkan yang dijadikan subyek penelitian sejumlah 25 siswa pada kelompok A dengan pertimbangan. Peneliti adalah guru kelompok A dan Kelompok A usianya antara 4-5 tahun. Penelitian ini merupakan Penelitian Tindakan Kelas (PTK) atau disebut dengan Classroom Action Research. Sedangkan alur penelitian tindakan mengacu pada teori Kemmis dan Taggart yang dimulai dari Tahap perencanaan, pelaksanaan tindakan, observasi (pengamatan), dan refleksi dalam setiap siklusnya dan direncanakan dilakukan dalam 2 siklus yang dapat digambarkan sebagai berikut:

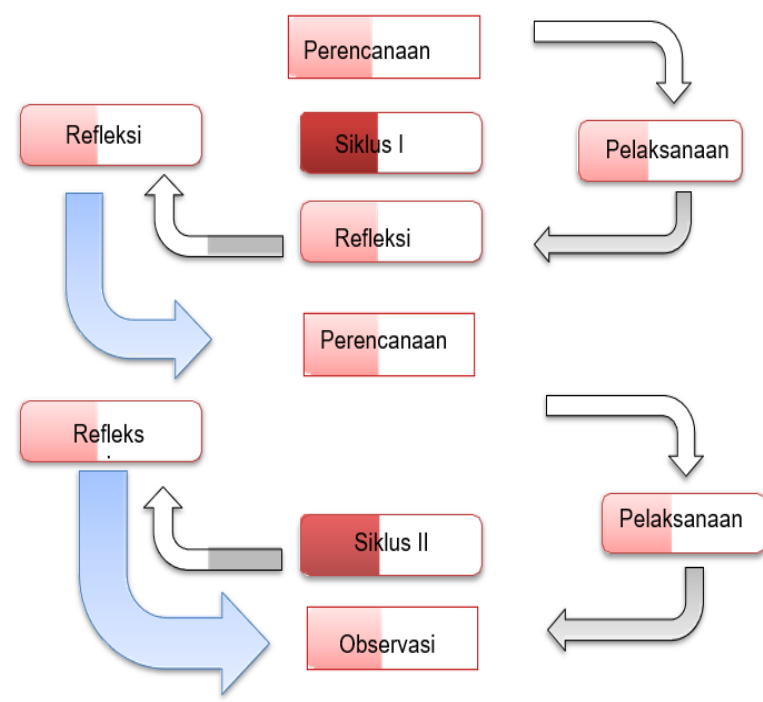

Gambar 2. Siklus Pelaksanaan Penelitian Tindakan Kelas

Adapun kegiatan persiklus yang dilakukan yaitu Tahap perencanaan, pelaksanaan tindakan, observasi (pengamatan), dan refleksi.yang dilakukan selama 1 minggu, kemudian dilanjutkan pada minggu berikutnya siklus II dyaitu Tahap perencanaan, pelaksanaan tindakan, observasi (pengamatan), dan . Refleksi pada siklus II ini akan menggunakan metode dalam hal ini metode yang digunakan yaitu model ATIK, sehingga dapat diketahui bahwa model ATIK dapat meningkatkan kegiatan menggambar pada anak usia dini di TK Pertiwi VI.Analisis data kualitatif digunakan untuk menentukan peningkatan proses belajar khususnya berbagai tindakan yang dilakukan guru, sedangkan analisis data kuantitatif digunakan untuk menentukan peningkatan hasil 
belajar siswa sebagai pengaruh dari setiap tindakan yang dilakukan guru, data yang sudah dikumpulkan melalui observasi, dianalisis menggunakan rumus presentase sederhana menurut (Muflikha, 2013) yaitu:

$$
P=\frac{f}{n} \times 100 \%
$$

Ket:

$\mathrm{P}=$ Persentase yang diperlukan

$\mathrm{F} \quad=$ Frekuensi nilai siswa

$\mathrm{N}$ = Jumlah anak dalam suatu kelas

\section{HASIL DAN PEMBAHASAN}

Dari hasil penelitian menunjukkan bahwa hasil observasi pada siklus I kemampuan menggambar anak mulai berkembang, hal ini dapat dilihat dari perolehan nilai rata-rata pada pertemuan 1, 2, 3 dan 4 terjadi perubahan yaitu meningkatnya kemampuan anak menggambar yang dapat dilihat dari jumlah akhir. Secara ringkas persentasi tingkat kemampuan menggambar pada siklus I dalam 4 kali pertemuan adalah sebagai berikut:

Tabel 1. Indikator Keberhasilan Anak Siklus I

\begin{tabular}{clcc}
\hline \multirow{2}{*}{ No } & \multirow{2}{*}{ Indikator Keberhasilan Anak } & \multicolumn{2}{c}{ Siklus I } \\
\cline { 3 - 4 } & & F & $\mathbf{\%}$ \\
\hline 1 & Berkembang Sangat Baik & - & - \\
\hline 2 & Berkembang Sesuai Harapan & 6 & 24 \\
\hline 3 & Mulai Berkembang & 10 & 40 \\
\hline 4 & Belum Berkembang & 9 & 36 \\
\hline & Jumlah & 25 & 100 \\
\hline
\end{tabular}

Dari tabel di atas menunjukkan bahwa ada peningkatan pada kemampuan menggambar hingga siklus I sebanyak 9 orang anak (36\%) yang belum berkembang, 10 orang anak (40\%) yang sudah mulai berkembang dan 6 orang anak (24\%) yang berkembang sesuai harapan. Hasil observasi pada siklus II kemampuan menggambar anak berkembang sangat baik, hal ini dapat dilihat dari skor rata-rata yang di peroleh anak yaitu dari perolehan nilai rata-rata pada pertemuan 1, 2, 3 dan 4 terjadi perubahan meningkatnya kemampuan anak menggambar yang dapat dilihat dari jumlah akhir. Secara ringkas persentasi menggambar pada siklus II dalam 4 kali pertemuan adalah sebagai berikut:

Tabel 2. Indikator Keberhasilan Anak Siklus II

\begin{tabular}{clcc}
\hline \multirow{2}{*}{ No } & \multirow{2}{*}{ Indikator Keberhasilan Anak } & \multicolumn{2}{c}{ Siklus II } \\
\cline { 3 - 4 } & & F & $\mathbf{\%}$ \\
\hline 1 & Berkembang Sangat Baik & 20 & 80 \\
\hline 2 & Berkembang Sesuai Harapan & 5 & 20 \\
\hline 3 & Mulai Berkembang & - & - \\
\hline 4 & Belum Berkembang & - & - \\
\hline & Jumlah & 25 & 100 \\
\hline
\end{tabular}

Dari tabel di atas menunjukkan bahwa ada peningkatan pada kemampuan menggambar dengan model ATIK hingga siklus II sebanyak 0 orang anak (0\%) yang belum berkembang, 0 orang anak $(0 \%)$ yang mulai berkembang dan 5 orang anak (20\%) yang berkembang sesuai harapan dan 20 anak (80\%) tergolong berkembang sangat baik

\section{SIMPULAN DAN SARAN}

\section{A. Simpulan}

Pembelajaran menggambar dengan model ATIK terbukti efektif dalam meningkatkan motorik halus pada anak usia dini di TK Pertiwi VI., dari hasil penelitian ini model ATIK dapat diperoleh peningkatan kemampuan anak dalam menggambar dan membuat anak juga bersemangat dalam menggambar

\section{B. Saran}

Pembahasan terkait penelitian ini masih sangat terbatas dan membutuhkan banyak masukan, saran untuk penulis selanjutnya adalah mengkaji lebih dalam dan secara komprehensif tentang Meningkatkan Motorik Halus melalui Kegiatan Menggambar dengan Model Atik di TK Pertiwi VI.

\section{DAFTAR RUJUKAN}

Abubakar Baraja. (2008). Psikologi Perkembangan (pp. 112-113). Studia Press.

Bruce R. Joyce, Bruce R Joyce, E. C. (2015). Models of Teaching. Pearson.

Dkk, S. A. (2011). Perkembangan dan Konsep Dasar Pengembangan Anak Usia Dini (p. 1.3).Universitas Terbuka.

Indraswari, L. (2012). Peningkatan Perkembangan Motorik Halus Anak Usia Dini Melalaui Kegiatan Mozaik Di Taman Kanak-Kanak Pembina Agam. Jurnal Pesona PAUD (Vol.1.No.1). HIm.2.Kasbolah, K. (1998). Penelitian Tindakan Sekolah. Jakarta: Departemen Pendidikan dan Kebudayaan Direktorat Jenderal Pendidikan Tinggi.

Loeloek Endah Poerwati. (2013). Penduan Memahami Kurikulum 2013 (1st ed.). Prestasi Pustaka.

Majid, A. (2013). Strategi Pembelajaran. PT Remaja Rosdakarya. 
Marliza. (2012). Peningkatan Kemampuan Motorik Halus Anak Melalui Permainan Melukis Dengan Kuas Taman Kanak-Kanak Pasaman Barat. Jurnal Pesona PAUD. (Vol.1.No.1). Hlm.1.

Muflikha, E. S. (2013). Peningkatan Kemampuan Anak Mengenal Huruf Melalui Media Tutup Botol Hias Di Paud Kenanga I Kabupaten Pesisir Selatan. SPEKTRUM PLS, 1, 29

Pamadhi, Hajar dkk. 2008.Seni Keterampilan Anak. Jakarta: Universitas Terbuka.

Rosmala Dewi. (2005). Berbagai Masalah Anak Taman Kanak-Kanak. Jakarta: Departemen Pendidikan Nasional.

Sunarsi, D., Wijoyo, H., \& Al Choir, F. (2020, October). Implementasi Pembelajaran Online Dalam Masa Pandemik Covid 19. In Prosiding Seminar Nasional LP3M (Vol. 2).
Watini, S. (2019a). Implementasi Model Pembelajaran Sentra pada TK Labschool STAI Bani Saleh Bekasi. Jurnal Obsesi : Jurnal Pendidikan Anak Usia Dini, 4(1), 110. https://doi.org/10.31004/obsesi.v4i1.190

Watini, S., \& Efendy, H. (2018). The Playing Method "ASYIK" Based on Multiple Intelligence in Learning Science Process at The Early Childhood Education Program (PAUD) Age5-6 Years. Journal of Studies in Education, 8(1), 51. https://doi.org/10.5296/jse.v8i1.12108 